\title{
ANALISIS PRODUKSI DAN PEMASARAN GULA MERAH DI DESA RUMBAI JAYA, KECAMATAN KEMPAS, KABUPATEN INDRAGIRI HILIR
}

\author{
Mulono Apriyanto Dan Yulianti \\ Teknologi Pangan, Universitas Islam Indragiri \\ Email : mulonoapriyanto71@gmail.com
}

\begin{abstract}
Abstrak
Tujuan dari penelitian ini adalah (1) untuk mengetahui proses produksi gula merah dibuat oleh pengrajin di desa Rumbai Jaya, Kecamatan Kempas, Kabupaten Indragiri Hilir, (2) untuk mengetahui faktor sosial ekonomi yang mempengaruhi produksi proses dan proses pemasaran gula merah di desa Rumbai Jaya, Kecamatan Kempas, Kabupaten Indragiri Hilir (3) untuk memecahkan masalah dan solusi yang dihadapi petani selama proses produksi dan pemasaran gula merah di desa Rumbai Jaya, Kecamatan Kempas, Kabupaten Indragiri Hilir, (4) untuk menganalisis proses pemasaran gula merah di desa Rumbai Jaya, Kecamatan Kempas, Kabupaten Indragiri Hilir. Penelitian ini menggunakan analisis primer dan sekunder. Metode penelitian yang digunakan oleh peneliti adalah menggunakan metode survei dengan responden 30. Dalam saluran pemasaran ada 2 pemasaran saluran sehingga akan mengetahui perbedaan harga, laba, dan saluran efektif untuk pengrajin gula merah.
\end{abstract}

Kata Kunci: Gula Kelapa, Rumbai Jaya, Proses pembuatan gula kelapa

\section{PENDAHULUAN}

Gula Jawa merupakan salah satu kebutuhan pokok manusia yang cenderung meningkat dari tahun ketahun. Gula merah dapat dimanfaatkan untuk pengolahan berbagai jenis makanan seperti roti kukus, bubur sumsum, dan lainlain. Dengan demikian, gula merah kelapa mempunyai peran penting dalam sistem pangan. Selain sebagai penyedia rasa manis, gula merah juga merupakan salah satu sumber kalori. Gula merah banyak dibutuhkan oleh manusia untuk dikonsumsi (Apriyanto 2019).

Gula merah mengandung; Mangan (Mn), Boron (B), Seng (Zn), Tembaga $(\mathrm{Cu})$, Nitrogen $(\mathrm{N})$, Fosfor $(\mathrm{P})$, Kalium $(\mathrm{K})$, Kalsium (Ca), Magnesium (Mg),
Natrium (Na), Klorin (CI) dan Belerang (Pratama et.al., 2015).

Gula kelapa merupakan salah satu produk yang prospektif dikembangkan di Kabupaten Indragiri Hilir (Mardesci, et al., 2019). Kempas merupakan salah satu kecamatan di Inhil yang memproduksi gula kelapa. Produksi gula kelapa di Kecamatan Kempas merupakan industri rumah tangga. Berdasarkan penelitian Mardesci, et al. (2017) yang meneliti tentang aspek finansial usaha gula kelapa di Kecamatan Kempas, dapat disimpulkan bahwa usaha gula kelapa tersebut layak dikembangkan.

Agar usaha pengembangan gula kelapa berjalan dengan sukses, maka 
perlu dilakukan analisis produksi dan pemasaran gula kelapa tersebut. Oleh sebab itu, penelitian ini perlu dilakukan. Penelitan ini bertujuan untuk:

1. Mengetahui proses produksi gula merah dibuat oleh pengrajin di desa Rumbai Jaya, Kecamatan Kempas, Kabupaten Indragiri Hilir

2. Mengetahui faktor sosial ekonomi yang mempengaruhi produksi proses dan proses pemasaran gula merah di desa Rumbai Jaya, Kecamatan Kempas, Kabupaten Indragiri Hilir

3. Memecahkan masalah dan solusi yang dihadapi petani selama proses produksi dan pemasaran gula merah di desa Rumbai Jaya, Kecamatan Kempas, Kabupaten Indragiri Hilir

4. Menganalisis proses pemasaran gula merah di desa Rumbai Jaya, Kecamatan Kempas, Kabupaten Indragiri Hilir

\section{METODE PENELITIAN}

Metode yang digunakan dalam penelitian ini adalah metode survey merupakan pendekatan yang digunakan untuk mendapatkan dari tempat tertentu yang alamiah (bukan buatan), tetapi peneliti melakukan perlakuan dalam pengumpulan data, misalnya dengan berdasarkan kuisioner, test, wawancara terstruktur dan sebagainya (Apriyanto et al. 2017)

\section{HASIL DAN PEMBAHASAN}

\section{Proses Pembuatan Gula Merah}

Taruh obat gula kedalam pongkor/drigen yang sudah dibersihkan, kaleng dibawa keatas pohon kelapa, digantung dimanggar (bunga kelapa) yang sudah diiris ujungnya. Air nira diambil setiap pagi dan sore hari. Siapkan wajan besar, saring air nira yang sudah diambil dengan menggunakan saringan, ini dilakukan agar lebah, kupu-kupu, bekas irisan manggar atau kotoran lain yang ikut kedalam air nira bisa dibersihkan dan tidak ikut termasak. Masak air nira selama kurang lebih 4 jam. Saat air nira sudah mulai berbusa, tutup dengan srumbung agar tidak tumpah kemanamana (Apriyanto dan Chairul, 2019).

Setelah 4 jam, air nira sudah berubah menjadi coklat kemerahmerahan menandakan gula merah sudah mulai jadi, angkat gula merah tersebut. Siapkan tempat cetakan, kemudian susun sengkang/cetakan gula. Gula diadukaduk hingga agak mengental, kemudian ambil sedikit demi sedikit dan tuangkan kedalam cetakan yang sudah disusun. Setalah itu tunggu gula mengeras. Gula merah merupakan gula yang berasal dari nira kelapa (Apriyanto et al. 2016). Dalam memproduksi gula merah pasti tidak selamanya mendapatkan kualitas yang baik dimana untuk mendapatkan kualitas nira yang bagus pasti mengalami kendala-kedala seperti faktor cuaca dimana faktor cuaca tersebut sangat mempengaruhi mutu gula merah, beberapa mutu gula merah :

a. Mutu Super adalah gula merah yang keras dan berwarna cerah atau coklat kekuning-kuningan.

Mutu gula merah super merupakan kualitas mutu yang paling bagus dibandingkan dengan mutu kualitas gula merah yang lain dimana mutu gula super ini akan dijual kepengepul keliling yang siap diambil oleh pengepul yaitu satu minggu sekali agar hasil produksinya banyak, setelah itu para pengepul menjual hasil produksi gula merah super tersebut ke luar daerah setempat dan juga mereka jual keindustri - industri seperti industri kecap dan industri roti kukus. 
b. Mutu A adalah gula merah yang keras dan berwana kecoklat-coklatan.

Mutu gula merah A merupakan mutu yang sedang dan para petani atau pengusaha gula merah mereka jual hasil produksinya ke daerah setempat, selain itu juga mereka jual kepengepul, dimana para pengepul menjual gula merah tersebut keluar daearah setempat seperti luar desa, kota.

c. Mutu B adalah gula merah yang agak lembek, berwarna coklat kehitamhitaman.

Mutu gula merah B merupakan mutu gula yang tidak layak untuk dijual dimana para petani atau pengusaha gula merah mutu gula B biasanya mereka gunakan sendiri untuk keperluannya.

Proses Pemasaran adalah suatu sistem keseluruhan dari kegiatankegiatan yang ditunjukan untuk merencanakan, menentukan harga, mempromosikan, dan mendistribusikan barang dan jasa, dan dapat memuaskan kebutuhan pembeli.

Didesa Rumbai Jaya, Kecamatan Kempas, Kabupaten Indragiri Hilir terdapat 40 penderes sekaligus pengrajin gula merah dimana mereka yang mengelola sekaligus memproduksi gula merah dan menghasilkan gula merah yang bervariasi mutu dan bentuk ukuran gula merah, di dalam mutu gula merah terdapat 3 mutu gula merah yaitu mutu super, mutu A, dan mutu B.

Distribusi adalah kegiatan yang menyangkut perencanaan dan pelaksanaan penyaluran barang dan jasa dari produsen kekonsumen.

\section{Faktor-Faktor Sosial Ekonomi Yang Mempengaruhi Proses Produksi dan Proses Pemasaran}

\section{Proses Produksi}

a) Keragaman Mutu Produk

Dalam menentukan mutu suatu produk banyak yang menjadi dasar penentuannya. Apalagi dalam menentukan mutu dari gula merah, ada banyak pertimbangan yang menjadi dasar untuk menyatakan gula merah yang berkualitas dan yang tidak. Kendalakendala yang dihadapi pengrajin gula merah yang berada di desa Rumbai Jaya, Kecamatan Kempas, Kabupaten Indragiri Hilir yaitu;

1. Mutu gula merah yang tidak sama antara pengrajin yangsatu dengan yang lain karena faktor cuaca yang sangat berpengaruh sehingga mutu gula merah berbeda-beda, selain itu juga faktor pohon juga berpengaruh antara pohon muda dengan pohon tua. Solusinya yaitu para petani penderes harus melihat kondisi tersebut dan untuk pohon yang tua bisa dipupuk dengan menggunakan pupuk organik agar nira yang diperoleh bagus.

2. Ukuran gula merah yang tidak sama antara pengrajin yang satu dengan yang lain karena cetakan yang dibuat oleh para pengrajin gula merah yang satu dengan yang lain tidak sama. Solusinya yaitu ada sosialisasi dari pemerintah, tokoh atau ketua kelompok tani yang bertanggung jawab agar ukuran gula merah yang berada desa Rumbai Jaya, Kecamatan Kempas, Kabupaten Indragiri Hilir (Apriyanto 2019).

3. Produksi gula merah yang tidak kontinyu salah satunya yaitu faktor usia dan kondisi badan sehingga dalam memproduksi gula merah tidak kontinyu. Solusinya yaitu para 
penderes sekaligus pengrajin gula merah harus menjaga kondisi badannya mereka mereka masingmasing agar mereka bisa memproduksi gula merah secara kontinyu.

4. Produksi yang dihasilkan pengrajin masih terbatas karena pohon kelapa sudah terlalu tua dan tidak pupuk sehingga nira yang dihasilkan tidak terlalu banyak. Solusinya yaitu pohon yang sudah tidak bisa menghasilkan nira sebaiknya diganti dengan pohon kelapa yang masih produktif atau para petani menanam pohon kelapa agar nantinya bisa dimanfaatkan oleh generasi berikutnya.

\section{KESIMPULAN DAN SARAN}

Faktor-faktor sosial ekonomi yang mempengaruhi proses produksi dan proses pemasaran adalah modal, jumlah tenaga kerja dan jumlah pohon yang dideres.

\section{DAFTAR PUSTAKA}

Mardesci, H., Santosa, N. Nazir, dan R.A. Hadiguna. 2017. Analisis Kelayakan Finansial Industri Kecil Gula Kelapa (Studi Kasus Di Kecamatan Kempas, Kabupaten Indragiri Hilir, Riau). Jurnal Teknologi Pertanian, Universitas Islam Indragiri. Vol. 6 No.1, Tahun 2017. Pp 19-25.

Mardesci, H., Santosa, N. Nazir, and R.A. Hadiguna. 2019. Identification of Prospective Product for the Development of Integrated Coconut
Agroindustry in Indonesia. IJASEIT. Vol. 9 (2019) No 2. Pp 511-517

Apriyanto Mulono,. 2019. Pelatihan Dan Pendampingan Pengolahan Komoditas Kelapa Jurnal Pengabdian Dan Pemberdayaan Masyarakat 3(2): 179-183

Apriyanto Mulono dan M Chairul Basrun Umanailo. 2019. "Decrease Polyphenols, Ethanol, Lactic Acid, and Acetic Acid during Fermentation with Addition of Cocoa Beans Innoculum." International Journal of Scientific \& Technology Research 8(10): 46165. www.ijstr.org.

Apriyanto Mulono, Sutardi, Eni Harmayani, and S Supriyanto. 2016. "Perbaikan Proses Fermentasi Biji Kakao Non Fermentasi Dengan Penambahan Biakan Murni Saccharomyces Cerevisiae , Lactobacillus Lactis , Dan Acetobacter Aceti." AGRITECH, 36(4): 410-15.

Apriyanto Mulono, Sutardi, Supriyadi, and Eni Harmayani. 2017. "Fermentasi Biji Kakao Kering Menggunakan

Saccharomycescerevisiae Lactobacillus Lactis , Acetobacter Aceti." AGRITECH 37(3): 302-11.

Pratama, F., W.H. Susanto, and I. Purwantiningrum. 2015. "Pembuatan Gula Kelapa Dari Nira Terfermentasi Alami (Kajian Pengaruh Konsentrasi Anti Inversi Dan Natrium Metabisulfit)." Jurnal Pangan dan Agroindustri 3(4): 1272-82. 
